\title{
(息)
}

Citation:

Hunter, S (2007) Negotiating professional and social voices in research principles and practice. Journal of Social Work Practice, 19 (2). pp. 149-162. ISSN 0265-0533 DOI: https://doi.org/10.1080/02650530500144709

Link to Leeds Beckett Repository record:

https://eprints.leedsbeckett.ac.uk/id/eprint/8435/

Document Version:

Article (Accepted Version)

Creative Commons: Attribution-Noncommercial 4.0

The aim of the Leeds Beckett Repository is to provide open access to our research, as required by funder policies and permitted by publishers and copyright law.

The Leeds Beckett repository holds a wide range of publications, each of which has been checked for copyright and the relevant embargo period has been applied by the Research Services team.

We operate on a standard take-down policy. If you are the author or publisher of an output and you would like it removed from the repository, please contact us and we will investigate on a case-by-case basis.

Each thesis in the repository has been cleared where necessary by the author for third party copyright. If you would like a thesis to be removed from the repository or believe there is an issue with copyright, please contact us on openaccess@leedsbeckett.ac.uk and we will investigate on a case-by-case basis. 
Negotiating Professional and Social Voices in Research Principles and Practice

Shona Hunter

Research Associate

Institute for Women's Studies

Cartmel College

Lancaster University

Lancaster

LA1 4YL.

Tel 01524592702

Email s.hunter@lancaster.ac.uk

Words (including notes and references) 6000 


\section{Negotiating Professional and Social Voices in Research Principles and Practice}

\section{Summary}

This paper draws on work conducted for a qualitative interview based study which explores the gendered racialised and professional identifications of health and social care professionals. Participants for the project were drawn from the professional executive committees of recently formed Primary Care Trusts. The paper discusses how the feminist psychosocial methodological approach developed for the project is theoretically, practically and ethically useful in exploring the voices of those in positions of relative power in relation to both health and social care services and the social relations of gender and ethnicity. The approach draws on psychodynamic accounts of (defended) subjectivity and the feminist work of Carol Gilligan on a voice-centred relational methodology. Coupling the feminist with the psychosocial facilitates an emphasis on voice and dialogic communication between participant and researcher not always captured in psychosocial approaches which tend towards favouring the interviewer as 'good listener'. This emphasis on dialogue is important in research contexts where prior and ongoing relationships with professional participants make it difficult and indeed undesirable for researchers to maintain silence. 


\section{Negotiating Professional and Social Voices in Research Principles and Practice}

Introduction

There is increasingly wide recognition that institutional racism and sexism occur across health and social care services with a number of government policy responses designed to counteract these tendencies. Whilst there is evidence of movement towards mainstreaming equality and diversity throughout organisational cultures (DTI/WEU, 2002), this is not without problems. The current thrust continues to favour a rather narrow approach to increasing the number of women and minority staff in decision making positions (see for example NHSE, 2000; NHSE, 2001). This seems (problematically) to assume that common identification between service user and provider on the basis of similar social location will override collective professional or organisational affiliations, or at the least that these are not in conflict.

A second, but related problem with current policies seeking to redress institutional discriminations is the failure to acknowledge the ambiguous relationship between institutional and individual racism and sexism within health and social care. Charges of the 'unwitting' (Macpherson, 1999) or unconscious reproduction of racist and sexist institutional norms within health and social care organisations heighten anxiety and confusion around issues 
of gender and ethnicity. Health and social care professionals within this context experience 'a recurrent, and disconcertingly unpredictable, encounter with self' where values, behaviour and professional practice are rendered visible and problematic (Husband, 1996, p.46). It is this 'encounter with self', the 'felt dimension' (Gunaratnam and Lewis, 2001, p.133) of organisational moves to integrate diversity, that I explore in the research discussed here ${ }^{1}$. The research aims to explore if and how health and social care practitioners recognise and reconcile potentially conflicting social and professional identifications and how these negotiations contribute to constructing, reconstituting or resisting institutional racism and sexism.

If these issues are to be taken seriously within health and social care research must consider the role of those with the power to develop policy making agendas, and to consider these individuals as emotional as well as rational actors (Hunter, 2003). Whilst there are increasingly sophisticated qualitative techniques applied to exploring the experience of health and social care users, there remains a paucity of work applying more reflexive narrative approaches to research with those holding such positions in the politics of health and social care (but see more recently Chamberlayne et al, 2004). In order to contest these imbalances I developed a feminist psychosocial methodology for this project. The framework draws on psychodynamic and feminist voice centred relational perspectives in order to achieve a more practically effective and ethical attitude towards the research process and encounter with welfare professionals. This article focuses on the challenges and benefits of adopting such an approach. 
The following extract comes from what was scheduled to be the end of my second interview with Lydia, a white woman nurse practitioner. It gives an example of the type of defensive responses participants gave to being asked to position the self as gendered and raced at work, and 'difficult' situations arising as a result. Prior to the point at which I introduced discussion around gender and ethnicity Lydia had been a 'good storyteller', positioning herself as the fictional character Shirley Valentine from the film of the same name, 'I was there, ten years ago, but it was subsumed by other things', and later positioning her husband (a British Asian GP) as the character of the father in the film East is East. After this point however, her story telling became stilted, with Lydia apparently no longer able to situate herself as gendered or raced within her stories. The extract comes from the end of the final section of the interview where we had moved to consider Lydia's experience of working in the PCG.

[Lydia] ... NO I CAN HONESTLY SAY, um and I think, that, that ALL of the women on the board have got respect from the MALE members of the board, and CERTAINLY nurses on the board have respect from their medical colleagues, and I don't feel its an issue for us, AT ALL.

[Shona] Ok, yea I see \{pause\} yea, I think we can draw it to a close for today if that's ok then.

[Lydia] \{pause\} I mean I don't know what you think, sitting on the board and seeing how we operate as an outsider, they DO talk a lot, but, but, sometimes, its not personal do you think? 
[Shona] \{pause\} Um, yea, um \{pause\} I'll link this into the wider results, 'cos one of the things I've been quite interested IN, when I'm asking about gender and ethnicity, um, is that most participants, regardless of ethnicity OR gender, which is what l'm finding interesting, have identified gender as being more important than ethnicity, um \{pause\} I think they were both probably bubbling under the surface \{pause\} but I don't think its useful to bash people over the head with these things, but ...

It is clear from my hesitant, somewhat garbled and indeed defended response here that I was placed in a dilemma in relation to Lydia's question, should I answer this and how? My decision to answer opened up a new methodological issue, suggesting a useful extension to the notion of the defended subject. In the paper I identify the psychodynamic notion of defended subjectivity as a useful methodological starting, moving on to explore how my subsequent response to Lydia's question and interaction with another participant Sam, suggest that 'being a good listener' is more complex than might sometimes be imagined. I finally highlight the contribution made by the work of Carol Gilligan and the Harvard Project on Women's Psychology and Girls' Development (The Harvard Project) on care and relational voice to enriching psychodynamic approaches to research practice.

\section{Methodological complexities with elite and defended group}

This project involved three primary care organisations with a range of Professional Executive Committee members interviewed from each. The notion of what constitutes an elite group remains contested (see Van Dijk, 
1993). Nevertheless, professional executive members of Primary Care Trusts can be regarded as an elite group in terms of their continuing ability to define elements of the policy making agenda (see Neal, 1998 for a similar perspective on elite groups). Equally, most participants in this project held positions of relative privilege in relation to either the politics of gender or ethnicity and many, in relation to both, participants being in most cases, white women or men.

Researchers are faced with a number of practical and ethical challenges to accessing and working with elite groups and in particular to developing participatory methods for research. The health and social care policy context is one of continual and rapid change characterised by a level of uncertainty and potential 'threat' experienced at the local policy development level in relation to Central Government initiatives (Foster and Wilding, 2000). There is a level of suspicion on the part of professionals with regards to being involved in research, particularly research of critical nature (Cassel, 1988). Acting on these suspicions elite participants also have the power to limit access and define research agendas 'in their own interests' (Duke, 2002). A final complication to this set of basic issues is the subject matter to be explored in this particular research. Within the current racialised and gendered context of health and social care (Gunaratnam, 2001; Lewis, 2000), researching and talking about gender and ethnicity and any impact this might have on working relationships and identities is rendered problematic. The subject matter of such research potentially provokes anxiety for participants, particularly if they are members of the dominant social group within racialised and gendered 
social relations (hooks, 1992). Gaining access to research sites and conducting interviews relating to these issues from a critical standpoint is particularly problematic.

Traditionally advice for researchers working with elite groups is based on the assumption that participants are in position of relative power over the researcher (Moysner and Wagstaffe, 1987). In this regard it suggests the opposite to more reflexive feminist standpoint approaches, which assume asymmetric power relations between researcher and researched, but this time in favour of the researcher (see Mies, 1993 for a detailed discussion of these). Both approaches advocate equalising research relationships, the former adopts strategies to 'protect' the researcher and the latter strategies to 'protect' participants. Both approaches assume unified rational subjectivity where participants voice and perspective are either reflective of power or disempowerment respectively. In contrast the power relationships involved in this research were multiple and contradictory and certainly were not characterised in terms of a one-dimensional hierarchical relationship between researcher and researched (see also Millen, 1997). Rather than constituting a comfortable trusting environment, research situations were characterised by anxiety. Designing the study as a whole and creating appropriate research 'tools' was under these circumstances potentially impossible if either elite approaches or feminist strategies were to be followed in a purist sense.

\section{Psychosocial conceptualisation of voice, silence and the defended subject}


In order to be able to grasp this range of methodological complexities, the perspective I adopted on voice in the research differs in its assumptions from both feminist standpoint and more positivistic elite approaches. It draws on psychodynamic accounts of subjectivity (Hollway and Jefferson, 2000) and relational identity and develops this in relation to a feminist voice-centered relational methodology (see Brown and Gilligan, 1992; McLean Taylor et al, 1995). As I have developed this the 'psycho' of this psychosocial coupling is therefore rooted in psychodynamic accounts of the self and identity and the 'social' is explicitly feminist.

\section{Complicating subjectivity}

The approach posits a 'defended subject' (Hollway and Jefferson, 2000) for whom there is no absolute and direct link between experience and voice. Social subjects don't always 'tell it like it is' (2000: 10-11) because they use unconscious defence mechanisms to split off unpalatable experience which threatens their sense of self. These defence mechanisms are discursive and relational developed through social relationships and psychic experience. Voice 'mediates' between identity and experience, where neither is stable nor fixed. In Hollway and Jefferson's (2000, p.33) terms voice is 'part of a defensive strategy ... of 'managing' painfully confusing emotional experiences through words which offer (apparently) the comfort of comprehension and the prospect of control'. This approach complicates the view of power as leading to 'distorted' knowledge suggested by some standpoint approaches (see Gill, 1998 for a similar argument). Subjects' voices do not constitute straightforward expressions of needs or desires and social actors are multiply 
positioned in relation to the social relations of power. Furthermore it recognises that whilst inhabiting the same subject position, as Hoggett (2001, p.53) suggests 'we can be both responsible and innocent'. Taking the example of this research we can at once deny and hate racist action, but on the other hand still perpetuate this by failing to act or speak against it. In terms of methods this framework favours narrative and [clinical] case study over more traditional and feminist standpoint approaches. The researcher's principal responsibility is to 'be a good listener' (2000, p. 31) through following the participant's lead in interviews. The aim of the approach is to facilitate participants to construct their own Gestalt ${ }^{2}$ via free association (2000, pp. 3237). In analysis, contradiction and inconsistency produced by free associations are cues to emotional resonance within the context of a whole research interaction (2000, p. 57).

\section{Connecting with elites}

This psychosocial perspective complicates notions of power, experience, identity and agency in research. One of its strengths is the considerable attention paid to both ethics and the inter and intra subjective and emotional construction of narratives. Nevertheless this approach should not be adopted uncritically. Experiences from my own research with 'elites' suggest two key difficulties, relating to the notion of the 'good listener' and to the 'framing' of the research and interview situation. Despite the recognition that researchers operate according to their own Gestalt which inevitably enters into interviews, there is a tendency to view occasions on which this occurs as introducing 'bias' or 'contaminating' participants' Gestalt. Hollway, for example (Hollway 
and Jefferson, 2000 p.51) describes 'censoring' her own beliefs in order to prevent them 'intruding' into the research situation (see also Wengraf, $2001 \mathrm{p}$. 163). Research framing is approached in a similar way. The basic assumption is that research designs usually involve giving little information about either the researcher or the research to potential participants. The aim is to avoid providing participants with a conscious or unconscious frame for interviews (Wengraf, pp. 188-190) ${ }^{3}$. There remains, however an overall tendency to view participants as potential 'victims of the research process' (Henry, 2003, p.239) who should be protected from the researcher's power to direct interviews and distort meaning.

The final interview design was in this case, an inevitable compromise. The interviews consisted of semi-structured biographical interviews and were split into four sections focusing on:

1. work and professional life

2. personal biography

3. gender and ethnicity

4. working relationships

Each section began with a broad 'tell me about...' question with a set of other questions to prompt and guide further discussion. Similar types of interview have been called interpretive biographies or guided interpretive biographies (Duncan, 2000, see also Belenky et al 1986 for a similar approach to interview design). Transcripts were to be returned to participants and at least one 
follow-up interview was to be conducted where issues raised in the first could be explored further.

The third section of the interview was the first point at which gender and ethnicity were introduced into the interview by the researcher. The choice to ask open and direct questions of participants about their own gendered and raced identifications and their meaning sits uneasily with narrative methods. However, the aim of asking such questions in this case were ethical and political, firstly in that these questions enabled participants to label themselves, and to explore the meaning of those labels and issues surrounding them. But, the questions were also designed as an explicit challenge to silenced or unacknowledged gendered or racialised power (see Hurtado and Stewart, 1997; Nakayama and Krizek, 1999). This discussion was however, prompted later rather than at the beginning of the interview, in order to avoid encouraging defensive or rehearsed responses in participants throughout the whole the interview (see Wengraf, 2001 pp. 145-156).

There were also a number of practical issues relating to the framing of research which necessitated a move away from the principles of free association. Accessing elites is often impossible without a great deal of research framing and negotiation around this prior to access being granted (Millen, 1997). Particularly where research is in some way solicited by participating organisations and/or individuals, as is often the case with policybased research, continuous negotiation is required. In this case the process involved establishing initial contact with potential organisations by letter, 
subsequent first meetings with Chief Executives, Chairs or Primary Care managers (in some cases all three), at which point a number of organisations decided not to continue with the research ${ }^{4}$. These initial meetings constituted the beginning of a lengthy process of negotiation around the presentation of the aims, objectives, methods to be used and potential outcomes of the research for consideration by the Professional Executive Committee (PEC). Thus instigating ongoing relationships with participants. After obtaining agreement to proceed from the PEC, I began ongoing attendance at PEC meetings and began identifying and contacting individuals to participate in interviews. Whilst avoiding framing was clearly impossible, the nature of this framing and negotiations around this were of importance. In particular it was important to avoid framing the research in terms of assuming racism and sexism or the evaluation of health and social care practitioners practice ${ }^{5}$. My analysis of the failure of previous research to explore the experiences of health and social care practitioners as caught up in 'the inherently contradictory logics of care and control, equity and rationing and empowerment and exploitation' (Hoggett, 2000a, p.147; see also Hunter, 2003) was therefore a useful starting point for negotiations. Specifically, it enabled me to establish myself as in some way sympathetic to difficulties encountered by health and social care practitioners in relation to their working lives.

These types of negotiation are ethically and practically problematic for a variety of reasons for several methodological approaches (see Birch and Miller, 2002; Miller and Bell, 2002 for a full discussion). What is important for 
this discussion is the contention that prior framing and exchange interferes with participants Gestalt. Because psychosocial approaches rarely assume a prior relationship with research participants they are less useful in accounting for situations which might occur in practice as the result of that pre-existing relationship. Furthermore, they often underestimate the utility of building these relationships for both participants and the research.

\section{Exchanging Stories}

Returning to Lydia's example. After my initially hesitant response represented in the earlier extract, I moved to open this out to elaborate more clearly on my preliminary analysis in terms of the gender dynamics occurring across PCTs also drawing on my own experiences at work. In this analysis, I acknowledged the ways in which women made themselves heard at work, but also how women were not 'heard' in the PCT and in my own experience in the university. Lydia engaged with this response by telling a number of her own stories focusing on her experiences married to and working with a British Indian GP. In these stories she explored the way in which this had enabled her to work across difference. Crucially she also began to tell stories around her own gendered disempowerment in relation to medicine her 'BIGGEST CHALLENGE'.

There are a number of interesting points here, but I want to consider how my answer enabled me to frame an environment in which Lydia could discuss gendered and raced experience, but in a less defensive way. Whereas participants' stories were often framed as gendered or raced they were almost 
universally unable to relate to these issues without unconsciously framing them negatively in terms of racism or sexism. The common pattern being participants who more obviously occupied a position of power within these relations (for example white men) seeking to diffuse or erase that power and those more obviously positioned in terms of disempowerment seeking to demonstrate their agency. So as in Lydia's case the unspoken framing of her previous stories symbolised in her identification with Shirley Valentine and presumably the mother of the family in East is East can be read as symbolic of her disempowerment in the past, but empowerment in the present. The fact that my positive framing often had to be continually re-established suggests the strength of the emotional defences surrounding these issues for participants. It was often only sharing my stories with participants which enabled them to explore their own relationship to gender and 'race' in less split terms viewing the self as both empowered and disempowered. My speaking in Lydia's example was also an ethical decision. Where participants ask about me, or the research, I should be ready to engage in the self exposure I am requesting of them. This is of course not to suggest that this self exposure involves the same risk. The following example from my interview with Sam, a white male GP explores this issue.

Sam adopted an antagonistic stance towards other members of the PCT (particularly women, nurses and the woman chief officer) and the organisation in general. I had therefore anticipated that achieving a 'successful' interview with him would be particularly difficult over and above the considerations mentioned in the earlier sections of this paper. Early in the interview Sam and 
I had happened upon an unanticipated connection between us. Both he and my brother had enjoyed working in parts of postcolonial Africa. Sam remembered his time working there fondly, recounting elements of this at length. He compared this favourably to his experiences as a GP in England, where he felt increasingly disempowered. When I introduced discussion around ethnicity and gender later in the interview however, Sam's response was unsure and defensive. In an effort to reconnect with Sam's experience I asked him to tell me about how this worked for him in Africa, this intervention re-established Sam's ability to tell racialised and gendered stories. However in doing so Sam connected his stories to my brothers' experience, prefacing his racist stories with 'your brother will probably tell you...'. At which point I moved to respond to Sam's story, but then noted the time and drew the exchange to an unusually abrupt halt.

Whilst offering my own story was practically effective in generating less defended positions from which others could speak as in both this case, and Lydia's this is not without tensions. In analysing the ongoing interaction between myself and Sam it was clear that the above example formed part of a pattern. This pattern consisted of me continually refocusing on Sam's experiences in Africa, facilitating dialogue around ethnicity, then immediately foreclosing on this dialogue. These foreclosures are useful to theorising my own anxieties related to speaking ethnicity in a way that does not reinforce the racialisation of social relations. One reading of the discomfort I felt in these interchanges, is that on some level I was aware that to encourage discussion around racialised others, when the 'object' of the research was to 'other' 
whiteness, constitutes another means of objectifying already racialised 'others' (see Dyer, 1997:11-14).

However another less comfortable reading of this exchange relates to my 'family story' (see Scott and Scott, 2000) of my brother's time in Zimbabwe which evokes strong feelings of ambivalence for me. Whilst 'out there' he taught in an SOS (Save Our Souls) school. The imposition of Christian education and Western medicine both constitute important elements of the Western 'civilising mission' in postcolonial Africa (see Ahmad, 1993). Sam's identification with my brother, draws attention to the ways in which my brother's story might reflect elements of his own. This identification at the very least positions them as similarly located within these social relations and Sam's comments suggest that my brother as a white man entering postcolonial Africa would hold the same views on the racialised social relations of this place. Both suggestions were perhaps too close for comfort. Another reading of my attempt to speak but then foreclose on dialogue in this instance, is as a defence against confronting painful emotions relating to my family's potentially very personal and immediate implication in the reproduction of colonial relations. Failing to confront this reality through speech enables me to project the responsibilities of colonialism onto Sam, simultaneously enabling me to inhabit unproblematically the position of antiracist.

The type of challenges that I encountered over the course of interviews are the sort which often prevent researchers from carrying out research with 
powerful groups (see Millen, 1997; Cassell, 1988), and would often be considered 'weaknesses' to be managed and accounted for in the data produced. In psychosocial approaches breaking participants' Gestalt seems similarly to require an explanation of breaking this, as a weakness in research design or conduct. As such this seems to underplay its key strength, the capacity to explore emotional dialogues (but see West, 2004 for an approach which capitalises on this strength). Adopting this approach too prescriptively may ironically lead to an under theorisation of the processes of subjection (See Byrne, 2003 for a similar argument).

\section{'Feminising' the Psychosocial: Interviews as situated ethical practice}

The work of Carol Gilligan and The Harvard Project also draws on psychodynamic conceptualisations of the self. Gilligan's (1982) work constitutes a radical epistemological critique of Freudian object relations and his clinical method (see also Gilligan, 2002). In her earlier work interviewing women and girls, Gilligan identified a relational or care voice which is culturally gendered as female, and accordingly denigrated. One of the key characteristics of this care voice is its ability to identify with multiple differentiated others and to view ethical dilemmas as relationship rather than principle based. One of the key dangers, however is the failure of those speaking in this voice to situate the self in these dilemmas. In the struggle to care for, listen to and remain connected to others, care for and connection to the self is overlooked. It is on this final point that a feminist voice centred relational methodology differs most markedly from the approaches discussed 
above. As a result it can be developed to enable a more practical, ethical and political approach to researching elites.

The notion of dialogue is crucial to this perspective on voice (Brown, 1998, see Clarke, 2002; Walkerdine et al, 2001 for other discussions of psychosocial interviews nearer to this). The expression of this care voice and indeed the ability to speak is dependent on the existence of a connected listener able to experience the physical and emotional reality of another's voice. The emphasis in this practice is placed on the mutual exchange of stories, 'telling one another stories' in order to create new stories (McLean Taylor et al, 1995, p. 212). Speech and listening are forms of interdependent social action which are intra and intersubjective (see Gilligan, 1993; Brown, 1994) what is important is how and in relationship with who the standpoint of the subject is produced. So, as with other psychosocial approaches subjects voices are not straight forward expressions of how things are, but are a means of negotiating in relationships with others different social identifications. Additionally however, voice is potentially a means of resisting oppressive normative definitions of identity and subjecthood for both researcher and participant (Brown and Gilligan, 1992; McLean Taylor et al, 1995). Listening should not only be active but also responsive. The approach to analysis is important here (see Brown et al, 1991; Gilligan et al, 1990). It focuses on reader response precisely in order to consider what the analyst might be able to hear and not hear, within the research situation, but also after this. The inter and intra subjective dynamics of the interview situation should be examined. More than this however, these should not be stifled in the 
ongoing research encounter. The dilemmas of when to speak and when to remain silent in research, are played out in concrete situations and should be 'resolved' with reference to those contexts and relationships of which they are constitutive.

With elite participants (or indeed any participant) where the researcher and the participant have already engaged in substantial dialogue participants will inevitably already have formed a conscious and unconscious frame for the research. What is important is to consider those frames 'in situ' and in analysis, rather than attempting to stifle these in the research situation. Returning to the two earlier examples, I am not suggesting that I did not 'interfere' with the Gestalt for either Sam or Lydia's stories. What I am suggesting is that this 'interference' enabled a richer (if inevitably still partial) understanding of how gendered and racialised defences operated.

\section{Conclusions}

This framework provides a more rounded approach to the researcher and research relationships than is allowed by the psychodynamic vestiges of some psychosocial approaches which tend towards viewing research relationships as 'as if' relationships. Rogers (1994, pp. 379-380), discussing therapeutic relationships makes a point relevant to notions of research relationships, '[research], after all, is a relationship that involves two people and any healing that might take place is actual, real and inevitably two-sided'. 
Whilst there are differences between them, both research and social situations occur in the context of psychosocially constructed relations, to suggest that research relationships either should be, or are, more or less so seems to miss the point. Adopting a perspective which suggests research and everyday social relations are different, fails to acknowledge that 'in practice, inclusiveness is produced in the micro-politics of day to day interaction (Schick, 2002:647). The key problem when applying such an approach uncritically in practice is that this may foster a lack of appreciation of research participants, particularly the researcher, as social actors capable of agency both in and against 'their own favour' in research situations. The silent researcher, who fails to attend to their own need for communication, challenge and resistance of the 'symbolic violence' perpetrated by research participants (Henry, 2003, p.238) within research situations, potentially fails to respond ethically to the self and others. Particularly so where research participants are relatively empowered within the research situation.

Using this feminist psychosocial perspective in the research did not make data collection any easier; I still faced the same dilemmas as researchers using a variety of perspectives. What it did do however was reconceptualise these dilemmas as something valuable to the research. Rather than something to be managed and accounted for after data collection, the 'problems' encountered when 'studying up' are no longer conceptualised as problems as such, but are crucial to our understanding of what it means to be located at the centre, and indeed the margins. The defences typically invoked 
by participants and myself in interview situations were important precisely because they indicated the ways in which we as participants negotiated gendered and racialised social relations and notions of profession and also how gendered and racialised identifications were defended against.

I am not advocating an approach which suggest that researcher is more important than participant, nor that researchers should use interviews as some sort of therapeutic encounter in which their anxieties be evacuated onto research participants (see Walkerdine et al, 2002). Rather, I am suggesting that, at least in certain research situations, silence, and 'being a good listener' on the part of the researcher may not necessarily be the most appropriate stance to adopt. It is an argument for a situated ethical approach to researchers as participants in a social process. It recognises that both participants' and researchers' experience can be both challenged, damaged and enriched through the process of research. The recognition that I too can be at once racist and anti-racist, powerful and powerless facilitating a confrontation with this element of myself is a much more ethical approach to adopt to myself and to participants in my research. It challenges the 'doubled splitting' which often goes on in research with the dominant, where 'we split ourselves from elite informants ... we then study the splitting that they produce with/against subjugated Others. We stabilize, essentialize, and render our elite informants 'Other"' (Fine, 1994, p.78). 


\section{Acknowledgments}

Earlier versions of this paper were presented to the Centre Local Democracy, Leadership, Voice and Accountability Global and Local Perspectives Conference, University of the West of England, 8-10 September 2003, and as part of the linked seminar series, 9 April 2003. I wish to thank the participants and organisers for valuable discussion around these ideas and in particular for the encouragement to seek publication of the paper. Equally I want to thank Prue Chamberlayne and Tom Wengraf for patiently reading and giving invaluable comments on later versions of the paper, also to Sara Ahmed for her comments and finally to Steven Briggs and the other anonymous referee for helpful advice around the final version.

\section{Notes}

${ }^{1}$ This research is ongoing, supported by an ESRC studentship ref. R42200124257.

${ }^{2}$ Gestalt constitutes the unconscious, 'deep' emotional logic which structures understanding and narratives.

${ }^{3}$ Hollway and Jefferson and Wengraf, all highlight how their methods do not imply objectivity and avoid methodological prescription. It is the emphasis placed on a lack of prior framing which I feel can be misconstrued if not approached with care.

${ }^{4} 60$ organisations were initially contacted by post. 7 responded positively to this initial contact (4 after receiving a second letter). After initial meetings only 2 finally agreed to participate, with a third agreeing 6 months later when it was planning to merge with one of the already participating organisations. A combination of factors were cited as contributing to decisions not to participate, these are too numerous to consider in detail here. However one consistently cited factor in this decision was the concern that GPs either would not be or had indicated that they were not willing to participate in research of this nature. This is interesting as it seems to support one of the key project findings around the emotional dynamics of PCG/Ts. Findings suggested that GPs as a group constituted symbolic bad objects within PCTs, onto which all of the anxieties of other PEC members around racism, sexism and the 'failure' of health and social care to deliver in terms of gender and 'race' equity were projected.

${ }^{5}$ Research framing was extensively piloted in a previous study focused only on hospital doctors and general practitioners, and then with other health and social care professionals in the first year of this project. This piloting was integral to developing the more open theoretical concept of social identity which enabled health and social care practitioners to engage with raced and gendered identification in ways that prioritising the concepts of gender and 'race' did not. It was, however made clear to participants that 'race' and gender were elements of social identity which were of key interest to me as a researcher. 


\section{Bibliography}

AHMAD, W. I. U. (1993) making black people sick: 'race', ideology and health research, in W. I. U. AHMAD (Ed) 'Race' and Health in Contemporary Britain, pp. 11-33 (Buckingham: Open University Press).

BELENKY, M. F., CLINCHY, B. M., GOLDBERGER, N. R. and TARULE, B. M. (1986) Women's Ways of Knowing: The Development of Self, Voice and Mind, (New York: Basic Books).

BIRCH, M and MILLER, T. (2002) Encouraging Participation: Ethics and Responsibilities, in: M. MAUTHNER, M. BIRCH, J. JESSOP and T. MILLER (Eds) Ethics in Qualitative Research, pp. 91-106, (Lodon: Sage).

BROWN, L. M. (1994) Standing in the Crossfire: A Response to Tavris, Gremmen, Lykes and Contratto, Feminism and Psychology, 4(3), pp. 382-398.

BROWN, L. M. (1998) Voice and Ventriloquation in Girl's Development: in K. HENWOOD, C. GRIFFIN and A. PHOENIX (Eds) Standpoints and Differences Essays in the Practice of Feminist Psychology, pp 91-114 (London: Sage).

BROWN, L. M. and GILLIGAN, C. (1992) Meeting at the Crossroads Women's Psychology and Girl's Development, (New York: Ballantine Books). BYRNE, B. (2003) Reciting the self: Narrative representations of the self in qualitative research, Feminist Theory, 4(1), pp. 29-49.

CASSEL, J. (1988) The Relationship of Observer to Observed When Studying Up, in R. G. BURGESS (Ed) Studies in Qualitative Methodology: Volume 1 Conducting Qualitative Research, pp 89-108 (London: Jai Press).

CHAMBERLAYNE, P., BORNAT, J. and APITZCH, U. (Eds) (2004)

Biographical Methods and Professional Practice: An international perspective, (Bristol: Policy Press).

CLARKE, S. (2002) Learning from experience: psycho-social research methods in the social sciences, Qualitative Research, 2(2), pp. 173-194. COLLINS, P. (1998) Negotiating Selves: Reflections on 'Unstructured' Interviewing Sociological Research Online, 3(3).

<http://www.socresonline.org.uk/socresonline/3/3/2.html> DEPARTMENT FOR TRADE AND INDUSTRY/WOMEN AND EQUALITY UNIT (2002) Equality and Diversity: Making it Happen (London: DTI). DUKE, K. (2002) Getting Beyond the 'Official Line': Reflections on Dilemmas of Access, Knowledge and Power in Researching Policy Networks, Journal of Social Policy, 31(1) pp. 39-59. 
DUNCAN, S. (2000) Undertaking Fieldwork and Data - A Four-Pronged Research Design, Workshop Paper No 18, Prepared for Workshop Four Methodologies for Researching Moral Agency, ESRC Research Group on Care, Values and the Future of Welfare, <http://www.leeds.ac.uk/cava/research/strand1/paper18Simon.htm> DYER, R. (1997) White (London: Routledge).

FINE, M. (1994) Working the Hyphens: Reinventing Self and Other in Qualitative Research, in N. K. DENZIN and Y. S. LINCOLN (Eds) Handbook of Qualitative Research, pp. 70-82 (Thousand Oaks, CA: Sage).

FOSTER, P. and WILDING, P. (2000) Whither Welfare Professionalism, Social Policy and Administration, 34(2), pp. 143-59.

FRANKENBERG, R. (1993) The Social Construction of Whiteness: White women, race matters, (Minneapolis: University of Minnesota Press).

GILL, R. (1998) Dialogues and Differences: Writing, Reflexivity and the Crisis of Representation in: K. HENWOOD, C. GRIFFIN and A. PHOENIX (Eds) Standpoints and Differences Essays in the Practice of Feminist Psychology, pp. 18-44 (London: Sage).

GILLIGAN, C. (1982) In A Different Voice Psychological Theory and Women's Development ( $2^{\text {nd }}$ ed) (London: Harvard University Press).

GILLIGAN, C. (2002) The Birth of Pleasure: A New Map of Love, (London: Chatto \& Windus).

GILLIGAN, C., BROWN, L. M. and ROGERS, A. G. (1990) Psyche Embedded: A Place for the Body, Relationships, and Culture in Personality Theory, in: A. I. RABIN, R. ZUCKER, R. EMMONS and S. FRANK (Eds) Studying Persons and Lives, pp. 86-147 (New York: Springer).

GUNARATNAM, Y. (2001) 'We mustn't judge people...but': staff dilemmas in dealing with racial harassment amongst hospice service users, Sociology of Health \& IIIness, 21(1), pp. 65-84.

GUNARATNAM, Y. and LEWIS, G. (2001) Racialising Emotional labour and emotionalising racialised labour: Anger, fear and shame in social welfare, Journal of Social Work Practice, 15(2), pp.131-148.

HENRY, M. G. (2003) 'Where are you really from?': representation, identity and power in the fieldwork experience of a South Asian diasporic, Qualitative Research, 3(2), pp. 229-242.

HOGGETT, P. (2001) Agency, Rationality and Social Policy, Journal of Social Policy, 30(1), pp. 37-56.

HOLLWAY, W. and JEFFERSON, T. (2000) Doing Qualitative Research Differently: free association, narrative and the interview method, (London: Sage).

HOOKS, B. (1992) Black Looks: race and representation, (Boston, MA: South End Press).

HUNTER, S. (2003) A Critical Analysis of Approaches to the Concept of Social Identity in Social Policy, Critical Social Policy, 23(3), pp. 322-344. HURTADO, A. and STEWART, A. J. (1997) Through the Looking Glass: Implications of Studying Whiteness for Feminist Methods, in: M. FINE, L.WEIS, L.C.POWELL and L. MUN WONG (Eds) Off White: Readings on Race, Power, and Society, pp. 297-311 (London: Routledge). 
HUSBAND, C. (1996) Defining and containing diversity: community, ethnicity and citizenship, in: W. I. U. AHMAD and K. ATKIN (Eds) 'Race' and Community Care, pp. 30-48 (Milton Keynes: Open University Press). KEZAR, A. (2003) Transformational Elite Interviews: Principles and Problems, Qualitative Inquiry, 9(3), pp. 395-415.

KITZINGER, C. and GILLIGAN, C. (1994) Listening to a Different Voice, Feminism and Psychology, 4(3), pp. 408-419.

LEWIS, G. (2000) 'Race', Gender, Social Welfare: Encounters in a Postcolonial Society, (Cambridge: Polity Press).

MACPHERSON, W. (1999) The Stephen Lawrence Inquiry, (London: Home Office).

MCLEAN TAYLOR, J., GILLIGAN, C. and SULLIVAN, A. M. (1995) Between Voice and Silence Women and Girls, Race and Relationship, (London: Harvard University Press).

MIES, M. (1993) towards a Methodology for Feminist Research, in: M. Hammersley (Ed) Social Research: Philosophy, Politics and Practice, pp. 6482 (London: Sage and Open University Press).

MILLEN, D. (1997) Some methodological and Epistemological Issues Raised by Doing Feminist Research on Non - Feminist Women, Sociological Research Online, 2(3).

<http://www.socresonline.org.uk/socresonline/2/3/3.html>

MILLER, T. and BELL, L. (2002) Consenting to What? Issues of Access, Gate-Keeping and 'Informed' Consent, in: M. MAUTHNER, M. BIRCH, J. JESSOP and T. MILLER (Eds) Ethics in Qualitative Research, pp. 53-69 (Lodon: Sage).

MOYSNER, G. (1988) Non-Standardized Interviewing in Elite Research, in: R. G. Burgess (Ed) Studies in Qualitative Methodology Vol 1: Conducting Qualitative Research, pp. 109-136 (London: Jai Press).

NAKAYAMA, T. K. and KRIZEK, R. L. (1999) Whiteness as Strategic

Rhetoric, in: T. K. NAKAYAMA and J. N. MARTIN (Eds) Whiteness: The Communication of Social ldentity, pp. 87-106 (London: Sage).

NATIONAL HEALTH SERVICE EXECUTIVE (2000) Positively Diverse Report 2000, (London: DoH).

NATIONAL HEALTH SERVICE EXECUTIVE (2001) The Vital Connection: An Equalities Framework for the NHS: Working Together for equality, (London: $\mathrm{DoH})$.

NEAL, S. (1998) Struggles with the research self: reconciling feminist approaches to antiracist research, in: P. CONNOLLY and B. TROYONA (Eds) Researching Racism in Education: Politics, Theory and Practice, pp. 109-121 (Buckingham: Open University Press).

ROGERS, A. G. (1994) Reply to Susan Contratto, Feminism and Psychology, 4(3), pp. 378-380.

SCOTT, S. and SCOTT, S. (2000) Our mother's daughters: Autobiographical inheritance through stories of gender and class, in: T. COSSLETT, C. LURY and P. SUMMERFIELD (Eds) Feminism and Autobiography: Texts, theories, methods, PP. 128-140, (London: Routledge).

SCHICK, R. S. (2002) When the Subject Is Difference: Conditions of Voice in Policy-Oriented Qualitative Research, Qualitative Inquiry, 8(5), pp. 632-651. VAN DIJK, T. A. (1993) Elite Discourse and Racism, (London: Sage). 
WALKERDINE, V., LUCEY, H. and MELODY, J. (2001) Growing Up Girl: Psychosocial Explorations of Gender and Class, (Basingstike: Macmillan). WALKERDINE, V., LUCEY, H. and MELODY, J. (2002) Subjectivity and Qualitative Method in: T. MAY (Ed) Qualitative Research in Action, pp. 179196 (London: Sage).

WENGRAF, T. (2001) Qualitative Research Interviewing, (London: Sage). WEST, L. (2004) Doctors on an edge: a cultural psychology of learning and health in: P. CHAMBERLAYNE, J. BORNAT and U. APITZCH (Eds) (2004) Biographical Methods and Professional Practice: An international perspective, pp. 299-311 (Bristol: Policy Press). 